\title{
ROLE OF PERCUTANEOUS IMAGE-GUIDED ABLATION OF MALIGNANT LIVER TUMORS: GLOBAL TRENDS AND CROATIAN PERSPECTIVE
}

\author{
LUKA NOVOSEL and DIJANA ZADRAVEC \\ Division of Diagnostic and Interventional Radiology, \\ Sestre milosrdnice University Hospital Center, Zagreb, Croatia
}

\begin{abstract}
Summary
Percutaneous minimally invasive methods are gaining space in oncologic treatment algorithms. Interventional radiology has a leading role in the last twenty years in developing percutaneous curative therapy for tumors of the parenchymal organs of the abdomen due to the precision of image-guided procedures. Ablative technology uses thermal energy for tumor tissue destruction. Compared to radiofrequency technology, microwave technology shows advantages in size of the liver tumors that can be ablated and the length of the procedure. Compared to surgery, both ablative techniques, enable shorter postprocedural time to chemotherapy, hospital stay and recovery time, reduced complication rate, and easier secondary ablation in case of new or residual tumors. Comparative advantages make these minimally invasive procedures, often the first choice in the treatment of hepatocellular carcinoma and liver metastases. Even though image-guided ablation is accepted in most European countries as a valid alternative to surgery in patients with unresectable hepatic tumors, currently, there is no algorithm for the use of this minimally invasive therapy in Croatia. Lack of clinical validation of thermal ablation in Croatia is mostly due to a limited number of the interventional radiologist with such focus along with limited patient referrals despite the published data about the potential advantages, efficacy, and safety of this technology.
\end{abstract}

KEYWORDS: percutaneous ablation, image-guided therapy, metastatic colorectal carcinoma, hepatocellular carcinoma, liver, interventional radiology

\section{ULOGA PERKUTANE SLIKOVNO VOĐENE ABLACIJE MALIGNIH TUMORA JETRE: SVJETSKI TRENDOVI I HRVATSKA PERSPEKTIVA}

\section{Sažetak}

Perkutane minimalno invazivne metode u dobivaju sve veću ulogu u algoritmu liječenja onkoloških pacijenata. Intervencijska radiologija kontinuirano razvija perkutane kurativne terapije parenhimskih organa abdomena zadnjih 20 godina, prije svega zbog napretka u preciznosti terapije vođene slikovnim metodama. Ablativna tehnologija koristi toplinsku energiju za destrukciju tumora. U usporedbi s radiofrekventnom tehnologijom, mikrovalna tehnologija je indicrana i za veće tumore jetre uz kraće vrijeme zahvata. U usporedbi s kirurškim zahvatima, ablativne tehnike omogućavaju kraće vrijeme hospitalizacije i oporavka, manju stopu komplikacija i mogućnost lakšeg ponavljanja zahvata u slučaju recidiva kao i brži nastavak liječenjadrugimmodalitetima primjerice kemoterapijom. Stoga su ove minimalno invazivne procedure sve čeśce metoda izbora u liječenju hepatocelularnog karcinoma i jetrenih metastaza. Iako je perkutana slikovno vođena ablacija prihvaćena u većini europskih zemalja kao vrijedna alternativa kirurgiji za liječenje pacijenata s resektabilnim tumorom jetre, trenutno u Hrvatskoj ne postoji prihvaćeni algoritam za korištenje ove minimalno invazivne terapije. Slabo kliničko vrednovanje termalne ablacije u Hrvatskoj je ponajprije posljedica postupnog povećanja broja intervencijskih radiologa u tom polju 
i relativno slabog upućivanja pacijenata unatoč dostupnosti publiciranih podataka o prednostima, učinkovitosti i sigurnosti ove tehnologije.

KLJUČNE RIJEČI: perkutana ablacija, slikovno vođene terapije metastatski kolorektalni karcinom, hepatocelularni karcinom, jetra, intervencijska radiologija

\section{INTRODUCTION}

Image-guided thermal ablation is used to treat a variety of liver tumors, ranging from focal primary hepatocellular carcinoma to metastatic colorectal and non-colorectal liver metastases (1-3). When compared to surgical resection advantages of percutaneous ablation include lower associated morbidity and mortality, the possibility of use in patients who are not surgical candidates, shorter recovery with greater cost-effectiveness $(4,5)$.

Colorectal cancer is the third most common malignancy in the world, and fifty percent of patients develop liver metastases (6). The development of hepatic metastases is the leading cause of death in patients with colorectal carcinoma. However, only up to $15 \%$ of these patients are candidates for surgical resection. Five-year survival after liver resection ranges from $30 \%$ and $58 \%$ while data suggests that after ablation survival varies from 17 to $51 \%(7,8)$. The remainder of the patients treated with chemotherapy has a five-year survival remaining close to $0 \%(7,8)$.

Hepatocellular carcinoma (HCC) is currently the second leading cause of cancer-related death; its incidence and mortality rates are increasing $(9,10)$. Even though surgical resection has the best long term results and survival, only a minority of HCC patients are surgical candidates, mostly due to comorbidities, liver function, lesion size or location and extrahepatic disease progression $(9,10)$. Percutaneous thermal ablation is recommended in the treatment of nonsurgical patients with earlystage HCC and metastatic disease limited only to the liver when these tumors are limited in size and number.

Most developed countries have accepted the existing quality improvement guidelines and expert position statements and recommendations, but there is still a lack of high value published evidence which would support clinical validation and creation of algorithms involving thermal ablation therapy of malignant liver tumors.
Another issue is that the existing recommendations usually cover only radiofrequency ablation (RFA) since it is the oldest, thereby the only thermal ablation technique with sufficient data for evidence-based approach $(11,12)$. However, RFA as therapy has known limitations such as ablation volume, predictability of ablation zone, and duration of the procedure.

Recently, new ablative technologies have emerged for focal tissue destruction. Since they overcame some of the RFA limitations, these technologies soon entered the common practice (1315). Microwave ablation (MWA) is a heat-based technology which uses specific wavelengths to achieve high temperatures in tissues, and as it continues to improve with newer devices, it is slowly taking over the leading role in the liver from RFA $(16,17)$.

Both RFA and MWA are thermal ablation techniques that use electromagnetic energy to cause rotation of water molecules. Tumor cells around the probe undergo denaturation of intracellular proteins and cell membranes. MWA spreads energy from the probe tip through the tissue and heats the tissue as waves attenuate which leads to deposition of energy in a larger volume than with RFA since electromagnetic energy requires no direct current flow, it overcomes the limitations of RFA regarding carbonization and evaporation of the tissue. One of the main advantages of MWA over RFA is avoiding the heat-sink effect or drain of energy on large vessels which are usually a relative contraindication for therapy with RFA when in the proximity of tumors (18). MWA also provides higher intratumoral temperatures, which can help treat cystic lesions, also sometimes problematic for treatment with RFA.

General lack of comprehensive understanding of the possible advantages of percutaneous ablation and shortage of interventional radiologists performing percutaneous non-vascular oncologic treatment methods has led to percutaneous ablative therapies being systematically involved in oncological treatment protocols much 
later and to a lesser extent in Croatia than in other developed countries. We started with percutaneous CT guided radiofrequency and microwave ablation in 2017 at our cancer center and since then we performed 56 ablations of malignant liver tumors, predominantly colorectal liver metastases, but also HCC and other liver metastases.

\section{INDICATIONS FOR LIVER ABLATION}

Indications for tumor ablation in any organ can be curative or palliative. Most of the recommendations and expert opinions revolve around curative intent in the liver tumors. The ablation is observed as an alternative method to surgery in achieving complete eradication of tumor tissue in patients who are not good surgical candidates. The ablation is also indicated for palliation, where it reduces tumor mass and achieves symptom relief and reduced risk of complications caused by the tumor progression.

One of the first society guidelines to incorporate ablation into its algorithm was the Barcelona Clinic Liver Cancer (BCLC) staging and treatment for HCC. In it, ablation is recommended as the treatment of choice for early stages of HCC, stage 0 (single lesion smaller than $2 \mathrm{~cm}$, Child-Pugh A, PSO 0), for patients who are not potential candidates for liver transplantation. For BCLC stage A patient surgical resection, liver transplantation, and ablation are the recommended lines of treatment. The American Association of the Study of the Liver Disease (AASLD) also has recommendations for ablation which include early-stage HCCs, smaller than $3 \mathrm{~cm}$ in size and less thanthree lesions, or cases of early-stage HCCs smaller than $2 \mathrm{~cm}$ but with additional complications such as portal hypertension. Surgery is still the standard of care in patients without complications such as portal hypertension, cirrhosis or high bilirubin, and early-stage HCC. These recommendations only mention RFA. Nevertheless, the studies proved that MWA has the same potential with possible added benefits and is often used in HCC treatment instead of RFA (19).

For liver metastases of colorectal cancer, indications are somewhat different than in HCC. In patients with colorectal liver metastases, up to $5 \mathrm{~cm}$ in size and/or with less than five liver lesions we consider ablation therapy, but individual pa- tient and tumor characteristics are $(19,20)$. In colorectal liver metastases ablation, specifically, MWA provides comparable results to surgery with 1, 2 and 3-year survival rates and mean survival times were $69 \%, 56 \%, 23 \%$, and 25 months after surgery and $71 \%, 57 \%, 14 \%$, and 27 months after MWA (21).

Relative and absolute contraindications for percutaneous ablative therapy in the liver include coagulation dysfunction, high extrahepatic tumor burden, liver failure with ascites, hepatic encephalopathy or other organ failures, tumor volume $>70 \%$ of the liver volume, active inflammation. Unlike in RFA, metallic foreign objects and pacemakers are not a contraindication for MWA (22).

\section{ABLATION RESULTS IN THE LITERATURE:}

Existing guidelines for HCC therapy put ablation before surgery in small or very small HCCs smaller than $3 \mathrm{~cm}$ because ablation has shown to cause much less loss in the normal liver parenchyma compared to surgical resection and is associated with fewer complications. Shorter recovery time is sometimes crucial for receiving the chemotherapy within an optimal timeframe.

A retrospective study by Zhang compared percutaneous RFA to MWA in HCCs smaller than $5 \mathrm{~cm}$ in 155 patients. Technical success was achieved in $83.4 \%$ RFA and $86.7 \%$ MWA treated patients. There was no significant difference in the 1, 3 and 5 -year overall survival and the 1, 3 and 5-year disease-free survival rates between the RFA and MWA groups (23). Furthermore, ultrasound-guided MWA was performed in 107 patients with large HCC with a technical success rate of $98.13 \%$ (24). Large HCC can be treated both with MWA and with chemoembolization, but this is sometimes considered a palliative indication. A comparison of the two methods showed that MWA had a lower incidence of recurrence with higher rates of complete ablation (75\%) (25). However, a prospective study involving patients with HCC smaller than $7 \mathrm{~cm}$ in diameter compared outcomes after RFA or MWA alone or in combination with TACE. It showed that combination therapies had superior survival compared to RFA or MWA alone (26).

Medium-sized single HCC tumors were treated in 182 patients in a study that showed technical rate of effectiveness of $93 \%$ and the re- 
currence-free survival and overall survival rates at 1,2 and 3 years to be $51 \%, 36 \%, 27 \%$ and $89 \%$, $74 \%, 60 \%$, respectively (27).

Percutaneous ablation therapy in HCC shows technical success rates ranging from 86 to $95 \%$ and progression-free survival of $91.7 \%$ for small lesions. One, 3 and 5-year survival rates following ablation ranges between $89-94 \%, 54-74 \%$ and $43-60 \%$.

In liver metastases, there are a few interesting studies investigating the efficacy and complications of MWA. Sixty-four patients with a single liver metastasis including colorectal cancer, breast cancer, carcinoid, melanoma, lung cancer, and anal cancer were followed for nine years after MWA ablation. The technical success rate of $95 \%$ was reported. The survival rates were 36.3 months for colorectal cancer metastases, and 13.9 months for other types compared to 38.3 months in HCC patients. When local recurrence at one year after ablation was observed there was a recurrence rate of $45.7 \%$ in colorectal metastases and $70.8 \%$ in other metastases compared to $39.8 \%$ in HCC.

Thermal ablation is very effective in treating small to medium-sized metastatic tumors. Many series reported trying to treat metastases over 5 $\mathrm{cm}$, up to 11 or $12 \mathrm{~cm}$, but the incomplete ablation and local recurrence rates were high. The most common cut-off point is $3 \mathrm{~cm}(28,29)$. However, tumors up to $5 \mathrm{~cm}$ can be ablated completely if their localization is accessible, and the proper protocol is applied. Hammil (29) reported a 3\% local recurrence rate for tumors smaller than $3 \mathrm{~cm}$ and $4 \%$ recurrence for 3 to $5 \mathrm{~cm}$ tumours, while recurrence rates for tumors larger than $5 \mathrm{~cm}$ remained higher, ranging from 27 to $45 \%$ and therefore ablation with curative intent should not be recommended for metastases over $5 \mathrm{~cm}$.

\section{OUR CENTER EXPERIENCE:}

We started with percutaneous CT guided radiofrequency and microwave ablation in 2017 at our cancer center and since then we performed 56 ablations of malignant liver tumors, predominantly colorectal liver metastases, but also HCC and other liver metastases.

All included patients at our institution were indicated for percutaneous thermal ablation of the liver by a multidisciplinary tumor team (MDT), which included surgeons, radiologists, and oncologists. With MDT's recommendation, the consultant surgeon and the interventional radiologist would explain possible treatment options and their risks to the patient. The patient was also informed about the need for long term CT or MRI follow-up that is required in the case of ablation therapy. The patients that accepted the treatment with percutaneous ablation were then included in the treatment protocol. Inclusion criteria for ablation in terms of the size of the lesion were dependent on the individual treatment strategy. Both curative ablations of small HCC and metastases (up to $5 \mathrm{~cm}$ ) were performed but also palliative ablation of lesions over $5 \mathrm{~cm}$ and multiple lesions or lesions with present extrahepatic spread, when additional extrahepatic therapy was planned. From January 2017 until May 2019, 56 patients were treated, 6 with RFA and 50 with MWA. There were 9 HCC treated, 38 colorectal metastases, 3 breast cancer metastases, 2 ovarian cancer metastases, 1 RCC metastasis, and 3 cholangiocarcinomas.

All patients underwent routine baseline laboratory investigations, including coagulation parameters (international normalized ratio [INR] $<1.5$ was required at the time of treatment and platelet count $>50000$ ), renal function tests (serum creatinine and urea measurement) and full blood count.

As advised by the international guidelines all patients had an abdominal computed tomography (CT) or magnetic resonance (MR) imaging performed at least 4 weeks prior to treatment. Six patients required a biopsy prior to ablation to confirm the diagnosis. The biopsy was performed in a prior session in all patients.

\section{CT-GUIDED RFA AND MWA PROCEDURE}

RFA was performed under general anesthesia in all patients. The procedure was performed with the Olympus Celon radiofrequency device with bipolar internally cooled electrodes, using one to three $10-15 \mathrm{~cm}$ electrodes at once depending on the size of the lesion. Local anesthesia was always used ( $1 \%$ Lidocaine). The MWA procedure was performed under general anesthesia in patients with multiple lesions treated all at once or when the tumor size was over $3 \mathrm{~cm}$. Smaller single lesions were treated under moderate sedation, and all received local anesthesia ( $1 \%$ Lidocaine). 
The microwave unit from HS Amica is capable of producing $100 \mathrm{~W}$ of power at $2450 \mathrm{MHz}$. The cooltip needle antenna has a diameter of $1.9 \mathrm{~mm}$ (14 gauge) and a length of $10-20 \mathrm{~cm}$. The antenna was percutaneously inserted into the tumor and placed at the desired location under CT guidance. A power output of $60-100 \mathrm{~W}$ was applied from 3 to 8 minutes depending on the size of the lesion, always in one needle placement.

Accurate imaging during ablation is essential for precise probe positioning, which proved to be one of the more crucial parts of the procedure in order to reduce complications and local recurrence. Using ultrasound monitoring during thermal ablation can be helpful for real-time monitoring, but there is a downside since usually, a hyperechogenic area appears early around the probe tip, which is caused by microbubbles and gas released from the heated tissue. This does not correlate with tissue coagulation as once thought, and these gas bubbles in the liver parenchyma can affect evaluation by overestimating the size of the ablated areas. This phenomenon will often disappear completely within onehour after ablation. Therefore, we monitor the positioning of the MWA antenna and the procedure under CT, which allows precise visualization of the vaporization process and early detection of possible complications, like bleeding or pneumothorax.

In 3 patients, we also used hydrodissection with $0.9 \%$ saline with a small amount of contrast injected between the targeted lesion and adjacent organs, usually the intestine in order to protect them from possible thermal damage.

\section{FOLLOW-UP}

The follow-up included routine postoperative physical examination, laboratory tests, and a three-phase contrast-enhanced CT or dynamic MRI imaging at 1, 4 and 12 months after treatment. Technique effectiveness was defined as the absence of enhancement of any residual areas of the lesion at a follow-up contrast-enhanced examination. Local recurrence was defined as the appearance of postcontrast enhancement more than 20 H.U. in scattered, nodular, or eccentric pattern inside or around the ablation zone. Interpreting post-ablation findings is sometimes not straightforward and demands a level of experience. A central zone of coagulation induced in most thermal therapies is generally accepted to represent coagulated tissue. The coagulation zone is usually surrounded by a red zone of hyperemia. On delayed contrast images, peripheral rim enhancement $(<20 \mathrm{HU})$ often surrounds the region of coagulation and indicates an inflammatory reaction due to thermally damaged cells. This can be either pseudoenhancement or represent minimal enhancement from leaky capillaries at the treatment margin. A bulky irregular rim at the edge of a treatment site is the most common appearance of an incompletely treated lesion.

\section{RESULTS}

From January 2017 to May 2019, 56 patients were treated at our institution, 6 with RFA, and 50 with MWA. Mean age of the patients was 64 years \pm 12.9 . Of the $9 \mathrm{HCC}$ treated, the mean tumor size was $2,9 \mathrm{~cm}$, with an average of 1,4 lesions. The procedure was technically effective in $77 \%$, with three retreatments required due to local recurrence or new lesions. There was one case of minor hemorrhage that did not require intervention. +

The patients reported higher pain levels in the first 8 hours after treatment with MWA, which resolved within the first 24 hours with analgesia. The patients who underwent general anesthesia took a long time to recover after treatment, and one patient complained of neck pain and had a broken tooth due to intubation.

Metastatic tumors were predominantly colorectal in origin, but there were also other carcinomas such as breast, RCC, ovarian, and cholangiocarcinoma. Lesion size was $3,2 \mathrm{~cm}$ on average, with 1,7 lesions treated per session. The local recurrence rate was 23\%, higher in lesions larger than $4 \mathrm{~cm}$ (up to $48 \%$ ), while lesions measuring up to $2 \mathrm{~cm}$ in size had a local recurrence rate of $8 \%$. There were two cases of serious complications requiring additional surgical therapy: one case of jejunal perforation due to thermal injury and one case of biliary obstruction requiring biliary intervention (30).

\section{CONCLUSION}

Thermal ablation is becoming accepted worldwide as a possible first-line therapy for very 
early $\mathrm{HCC}$, inoperable HCC and oligonodular liver metastases smaller than $3 \mathrm{~cm}$ in selected patients with comorbidities. Even though strong evidence from prospective randomized controlled trials are not available, yet there is sufficient data that supports the use of percutaneous CT-guided ablation for a subgroup of liver carcinomas and metastases.

International guidelines for HCC recommend RFA due to the abundance of published evidence compared to other technologies. The known advantages of MWA over RFA and surgery make this method a new tool in both inoperable and operable primary and secondary liver tumors with the advantage of lower morbidity, mortality, and easier redo.

Thermal ablation methods were long underestimated and overlooked in the oncological treatment protocols in Croatia due to multiple factors, but since 2017 RFA and MWA of liver tumors is an available treatment with initial results showing promising results.

\section{REFERENCES:}

1. Lencioni R, Cioni D, Crocetti L, et al. Early stage hepatocellular carcinoma in patients with cirrhosis: longterm results of percutaneous image-guided radiofrequency ablation. Radiology 2005;234(3):961-967.

2. Meloni MF, Andreano A, Laeseke PF, Livraghi T, Sironi S, Lee FT Jr. Breast cancer liver metastases: US-guided percutaneous radiofrequency ablationintermediate and long-term survival rates. Radiology. 2009;253(3):861-869.

3. Solbiati L, Ahmed M, Cova L, Ierace T, Brioschi M, Goldberg SN. Small liver colorectal metastases treated with percutaneous radiofrequency ablation: local response rate and long-term survival with up to 10-year follow-up. Radiology. 2012;265(3):958-968.

4. El-Serag HB. Hepatocellular carcinoma. N Engl J Med. 2011;365(12):1118-1127.

5. Ahmed M, Brace CL, Lee FT Jr, Goldberg SN. Principles of and advances in percutaneous ablation. Radiology. 2011;258(2):351-369.

6. Bale R, Widmann G, Schullian P, Haidu M, Pall G, Klaus A, Weiss H, Biebl M, Margreiter R. Percutaneous stereotactic radiofrequency ablation of colorectal liver metastases. Eur Radiol. 2012; 221:930-7.

7. Choti MA, Sitzmann JV, Tiburi MF, Sumetchotimetha W, Rangsin R, Schulick RD, Lillemoe KD, Yeo CJ, Cameron JL. Trends in long-term survival following liver resection for hepatic colorectal metastases. Ann Surg. 2002;52:759-66.
8. Kornprat $\mathrm{P}$, Jarnagin WR, Gonen M, Dematteo RP, Fong Y, Blumgart LH, D’Angelica M. Outcome after hepatectomy for multiple (four or more) colorectal metastases in the era of effective chemotherapy. Ann Surg Oncol. 2007;212:1151-60.

9. Bruix J, Sherman M. American Association for the Study of Liver Diseases: Management of hepatocellular carcinoma: an update. Hepatology. 2011;53:1020-1022.

10. Adams RB, Aloia TA, Loyer E, Pawlik TM, Taouli B, Vauthey JN. Selection for hepatic resection of colorectal liver metastases: expert consensus statement. HPB Oxf. 2013;15:91-103.

11. Gervais DA, Goldberg SN, Brown DB, Soulen MC, Millward SF, Rajan DK. Society of Interventional Radiology position statement on percutaneous radiofrequency ablation for the treatment of liver tumors. J Vasc Interv Radiol. 2009;20(Suppl):S342-S347.

12. Crocetti L, de Baere T, Lencioni R. Quality improvement guidelines for radiofrequency ablation of liver tumours. Cardiovasc Intervent Radiol. 2010;33:11-17.

13. Lubner MG, Brace CL, Ziemlewicz TJ, Hinshaw JL, Lee FT. Microwave ablation of hepatic malignancy. Semin Intervent Radiol. 2013;30:56-66.

14. Lu DS, Kee ST, Lee EW. Irreversible electroporation: ready for prime time? Tech Vasc Interv Radiol. 2013; 16:277-286.

15. Erinjeri JP, Clark TW. Cryoablation: mechanism of action and devices. J Vasc Interv Radiol. 2010;21:187-191.

16. Martin RC, Scoggins CR, Mcmasters KM. Safety and efficacy of microwave ablation of hepatic tumors: a prospective review of a 5-year experience. Ann Surg Oncol. 2010;17:171-178.

17. Groeschl RT, Pilgrim CH, Hanna EM, et al. Microwave ablation for hepatic malignancies: a multiinstitutional analysis. Ann Surg. 2014;259:1195-1200.

18. Yang D, Converse MC, Mahvi DM. et al. Measurement and Analysis of Tissue Temperature During Microwave Liver Ablation. IEEE Trans Biomed Eng. 2007;54: 150-155.

19. Foltz G. Image-guided percutaneous ablation of hepatic malignancies. Semin Intervent Radiol. 2014;31: 180-186.

20. de Baere T, Tselikas L, Yevich S. et al. The role of imageguided therapy in the management of colorectal cancer metastatic disease. Eur J Cancer. 2017;23:231-242.

21. Shibata T, Niinobu T, Ogata N. et al. Microwave coagulation therapy for multiple hepatic metastases from colorectal carcinoma. Cancer. 2000;89:276-284.

22. Ping Liang, Jie Yu, Ming-De Lu. et al. Practice guidelines for ultrasound-guided percutaneous microwave ablation for hepatic malignancy. World J Gastroenterol. 2013;19:5430-5438.

23. Zhang L, Wang N, Shen Q. et al. Therapeutic efficacy of percutaneous radiofrequency ablation versus microwave ablation for hepatocellular carcinoma. PLoS One. 2013;8:e76119. 
24. Liu F, Yu X, Liang P. et al. Contrast-enhanced ultrasound-guided microwave ablation for hepatocellular carcinoma inconspicuous on conventional ultrasound. Int J Hyperthermia. 2011;27:555-562.

25. Abdelaziz AO, Nabeel MM, Elbaz TM. et al. Microwave ablation versus transarterial chemoembolization in large hepatocellular carcinoma: prospective analysis. Scandinavian Journal of Gastroentereology. 2015; 50:479-484.

26. Yi Y, Zhang Y, Wei Q. et al. Radiofrequency ablation or microwave ablation combined with transcatheter arterial chemoembolization in treatment of hepatocellular carcinoma by comparing with radiofrequency ablation alone. Chin J Cancer Res. 2014;26:112-8.

27. Ai-Xue Sun, Zhi-Li Cheng, Pan-Pan Wu. et al. Clinical outcome of medium-sized hepatocellular carcinoma treated with microwave ablation. World J Gastroenterol. 2015;21:2997-3004.

28. Hamada A, Yamakado K, Nakatsuka A, Uraki J, Kashima M, Takaki H, Yamanaka T, Inoue Y, Kusuno- ki M, Takeda K. Radiofrequency ablation for colorectal liver metastases: prognostic factors in non-surgical candidates. Jpn J Radiol. 2012;324:567-74.

29. Hammill CW, Billingsley KG, Cassera MA, Wolf RF, Ujiki MB, Hansen PD (2011) Outcome after laparoscopic radiofrequency ablation of technically resectable colorectal liver metastases. Ann Surg Oncol. 2011; 13:1947-54.

30. Novosel L, Pezelj I, Tomašković I, Zadravec D. Initial experiences comparing CT-guided radiofrequency and microwave ablation in the treatment of renal carcinoma. Libri Oncologici, 2018;46(1):14-19.

Corresponding author: Luka Novosel, Clinical Department of Diagnostic and Interventional Radiology, Sestre milosrdnice University Hospital Center, Vinogradska 29, 10000 Zagreb,Croatia.e-mail: novosel0701@gmail.com 